\title{
Sol-Gel Coatings for Chemical Protection of Stainless Steel
}

\author{
Code: EP7 \\ PEDRO DE LIMA NETO, MOHAMED ATIK, LUIS A. AVACA AND MICHEL A. AEGERTER \\ Institute of Physics and Chemistry of São Carlos, University of São Paulo, Cx. Postal 369 -13560-970-São Carlos (SP), Brazil
}

\begin{abstract}
Sol-gel thin coatings of $\mathrm{ZrO}_{2}, \mathrm{SiO}_{2}, 70 \mathrm{SiO}_{2}-30 \mathrm{TiO}_{2}$ and $88 \mathrm{SiO}_{2}-12 \mathrm{Al}_{2} \mathrm{O}_{3}$ compositions (mole \%) have been prepared from sonocatalyzed sols and deposited by dip-coating technique on 316L stainless steel foils. The influence of the coatings on the chemical corrosion of the substrate has been measured through potentiodynamic polarization curves in aqueous $15 \% \mathrm{H}_{2} \mathrm{SO}_{4}$ solution between 25 and $50^{\circ} \mathrm{C}$. The values of the corrosion potential, polarization resistance and corrosion rate have been determined. Analysis of the data combined with scanning electron microscopy studies indicate that the films act as a geometric blocking against exposure to the corrosive media and increase the lifetime of the substrate up to a factor 8.5 .
\end{abstract}

Keywords: thin film, $\mathrm{ZrO}_{2}, \mathrm{SiO}_{2}, \mathrm{SiO}_{2}-\mathrm{TiO}_{2}, \mathrm{SiO}_{2}-\mathrm{Al}_{2} \mathrm{O}_{3}$, corrosion protection, stainless steel $316 \mathrm{~L}$

\section{Introduction}

Sol-gel methods are now widely used for the preparation of films of oxide materials from solutions and offer potential advantages over traditional techniques [1] [2] [3] [4]. The chemical processing [5] and the technical applications [6], which encompass optical,electronic, optoelectronic, photonic, biotechnology, chemical and mechanical fields have been reviewed recently.

Inorganic coatings having a vitreous structure are widely used as protective coatings for metals and alloys [7] [8]. They improve the chemical and physical properties of the metal surfaces relative to corrosion, friction and wear without altering the original properties of strength and toughness of the substrate.

The preparation and characterization of sol-gel films having these specific chemical and mechanical functions have been so far scarcely studied. $\mathrm{Al}_{2} \mathrm{O}_{3}$ [9], $\mathrm{Si}-\mathrm{O}-\mathrm{N}, \mathrm{Si}_{3} \mathrm{~N}_{4}$ [10] [11] films have been proposed for semiconductor passivation. $\mathrm{SiO}_{2}[12]$ and $\mathrm{TiO}_{2}-\mathrm{SiO}_{2}$ [13] are known to prevent alkali diffusion. The prevention of chemical corrosion and oxidation of mild steel, carbon steel and stainless steels has been tested with $\mathrm{SiO}_{2}$ [14], $\mathrm{SiO}_{2}-\mathrm{B}_{2} \mathrm{O}_{3}$ [15] [16], mullite [17], $\mathrm{ZrO}_{2}$ [15, 18-22], MTOS [23] and $\mathrm{ZrO}_{2}-\mathrm{CeO}_{2}$ [24] coatings. They all increase the protection of metal substrates from air corrosion (tested up to $800^{\circ} \mathrm{C}$ ) and acid attack (tested up to $80^{\circ} \mathrm{C}$ ). The most promising prevention for stainless steel has been so far reported by our group using sol-gel film of $\mathrm{ZrO}_{2}, \mathrm{SiO}_{2}-\mathrm{TiO}_{2}$, $\mathrm{SiO}_{2}-\mathrm{Al}_{2} \mathrm{O}_{3}$ and $\mathrm{TiO}_{2}-\mathrm{CeO}_{2}$ prepared by dip-coating using sonocatalyzed sols $[18,19,21,25]$.

In this paper we present the results of a systematic electrochemical corrosion study in $15 \%$ aqueous $\mathrm{H}_{2} \mathrm{SO}_{4}$ up to $50^{\circ} \mathrm{C}$ of sol-gel films of $\mathrm{ZrO}_{2}, \mathrm{SiO}_{2}-$ $\mathrm{TiO}_{2}, \mathrm{SiO}_{2}-\mathrm{Al}_{2} \mathrm{O}_{3}$ (mole\%) deposited on stainless steel $316 \mathrm{~L}$ by dip coating, a material widely used for marine and chemical industry environments.

\section{Experimental}

316L stainless steel substrates (Caseurop, France) were cut from large foils and degreased ultrasonically in acetone. This austenitic material was chosen because it has a low carbon content $(<0.03 \%)$ and is therefore less susceptible to sensitization during the heat treatment necessary for the densification of the coatings.

The zirconia sol was prepared by dissolving the alkoxide $\mathrm{Zr}\left(\mathrm{OC}_{3} \mathrm{H}_{7}\right)_{4}$ in isopropanol $\left(\mathrm{C}_{3} \mathrm{H}_{7} \mathrm{OH}\right)$ with a small amount of acetic acid $\left(\mathrm{CH}_{3} \mathrm{COOH}\right)$. Excess water was then added to complete the hydrolysis. The concentration of the alkoxide was varied between 0.025 and 0.9 mole/ $/ \mathrm{ZrO}_{2}$. The volume ratios $\mathrm{H}_{2} \mathrm{O} / \mathrm{C}_{3} \mathrm{H}_{7} \mathrm{OH}$ and $\mathrm{H}_{2} \mathrm{O} / \mathrm{CH}_{3} \mathrm{COOH}$ were respectively equal to 1 and 2. The silica sol was prepared by dissolving tetraethylorthosilicate $\mathrm{Si}\left(\mathrm{OC}_{2} \mathrm{H}_{5}\right)_{4}$ in absolute 


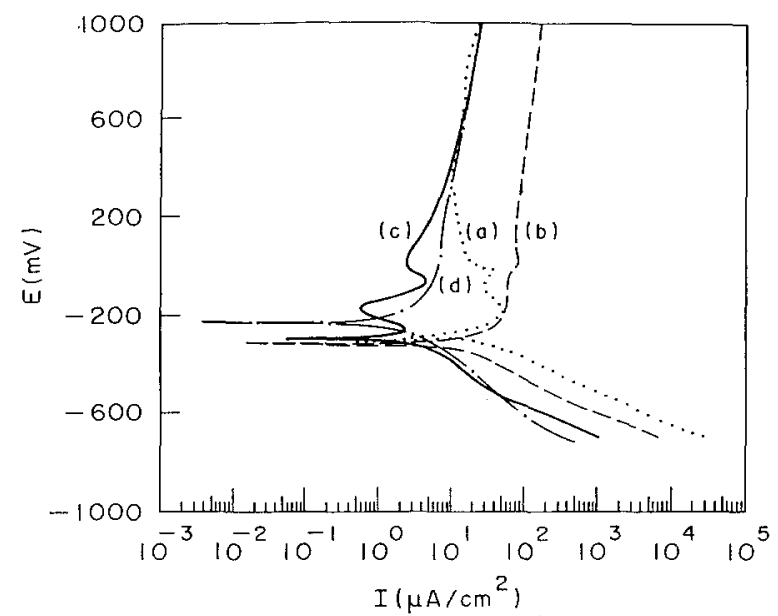

Fig. 1. Potentiodynamic polarization curves measured in deareated $15 \%$ aqueous $\mathrm{H}_{2} \mathrm{SO}_{4}$ at $25^{\circ} \mathrm{C}$ for $316 \mathrm{~L}$ stainless steel a) uncoated and untreated, b) uncoated but heat treated at $800^{\circ} \mathrm{C}$ for $2 \mathrm{~h} ., \mathrm{c}$ ) coated with $\mathrm{ZrO}_{2}\left(800^{\circ} \mathrm{C} / 2 \mathrm{~h}\right)$, d) coated with $\mathrm{SiO}_{2}\left(800^{\circ} \mathrm{C} / 2 \mathrm{~h}\right)$.

ethanol $\mathrm{C}_{2} \mathrm{H}_{5} \mathrm{OH}$ (0.43 mole/mole of alkoxide) to which a small amount of acetic acid $\mathrm{CH}_{3} \mathrm{OOH}(0.087$ mole/mole of alkoxide) was added. Binary compositions in the system $\mathrm{SiO}_{2}-\mathrm{TiO}_{2}$ and $\mathrm{SiO}_{2}-\mathrm{Al}_{2} \mathrm{O}_{3}$ have been prepared using the same protocol and concentration using $\mathrm{Si}\left(\mathrm{OC}_{2} \mathrm{H}_{5}\right)_{4}$, tetraorthotitanate $\mathrm{Ti}\left(\mathrm{OC}_{2} \mathrm{H}_{5}\right)_{4}$ and aluminum sec-butilate $\mathrm{Al}\left(\mathrm{OC}_{4} \mathrm{H}_{5}\right)_{3}$ as source of $\mathrm{Si}$, $\mathrm{Ti}$ and $\mathrm{Al}$ respectively. The composition of the solutions were $x \mathrm{SiO}_{2}(1-x) \mathrm{M}_{y} \mathrm{O}_{z}$ where $\mathrm{M}=\mathrm{Ti}$ or Al with $x=70$ mole $\%\left(70 \mathrm{SiO}_{2}-30 \mathrm{TiO}_{2}\right)$ and $x=88$ mole $\%$ $\left(88 \mathrm{SiO}_{2}-12 \mathrm{Al}_{2} \mathrm{O}_{3}\right)$. However a complete study with $0<x<100$ for both binary systems is underway and will be published elsewhere. All the sols were submitted to intense ultrasonic irradiation (Heat Systems Ultrasonics W385). They became homogeneous and transparent after 25 minutes and were stable up to 4 weeks at room temperature when kept in a close vessel.

Single layer coatings have been deposited by dip coating technique at a constant withdrawal speed of $10 \mathrm{~cm} \mathrm{~min}{ }^{-1}$, dried at $60^{\circ} \mathrm{C}$ for $15 \mathrm{~min}$. and then treated in air at a slow rate of $5^{\circ} \mathrm{C} \mathrm{min}^{-1}$ up to $800^{\circ} \mathrm{C}$, with an intermediate isothermal holding at $450^{\circ} \mathrm{C}$ during $1 \mathrm{~h}$ and further isothermal treatments at $800^{\circ} \mathrm{C}$ up to $20 \mathrm{~h}$. The coatings have a thickness of about 0.3 to $0.6 \mu \mathrm{m}$. $1^{\circ}$ glancing incidence $\mathrm{X}$-ray diffraction (Rigaku Rotaflex) shows that the heat treated $\mathrm{SiO}_{2}$ and $88 \mathrm{SiO}_{2}-12 \mathrm{Al}_{2} \mathrm{O}_{3}$ coatings are amorphous; however $\mathrm{ZrO}_{2}$ coatings crystallized at $\sim 450^{\circ} \mathrm{C}$ into a tetragonal structure [21] while $70 \mathrm{SiO}_{2}-30 \mathrm{TiO}_{2}$ coatings partially

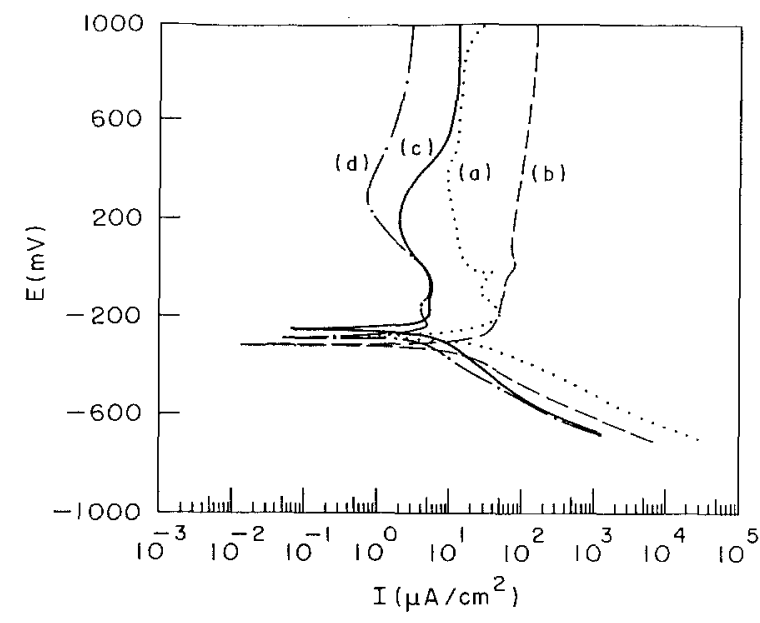

Fig. 2. Same as figure 1 for $\mathrm{T}=25^{\circ} \mathrm{C}$ a) and b) same as in Figure 1 (for reference); c) coated with $\mathrm{SiO}_{2}-\mathrm{TiO}_{2}\left(800^{\circ} \mathrm{C} / 2 \mathrm{~h}\right)$; d) coated with $\mathrm{SiO}_{2}-\mathrm{Al}_{2} \mathrm{O}_{3}\left(800^{\circ} \mathrm{C} / 2 \mathrm{~h}\right)$.

crystallized at $\sim 650^{\circ} \mathrm{C}$ showing anatase crystallites in an amorphous silica matrix [21].

Electrochemical measurements are convenient and precise methods to evaluate the corrosion of a material in a given medium [26]. They have been carried out with freshly prepared samples in deareated $15 \% \mathrm{H}_{2} \mathrm{SO}_{4}$ (Merck p.a.) aqueous solutions (Milli-Q) up to $50^{\circ} \mathrm{C}$ using a computerized PAR 273 Potentiostat/Galvanostat. A saturated calomel electrode (SCE) was used as reference and a Pt foil served as the auxiliary electrode. The working electrodes were immersed $1 \mathrm{~cm}$ into the solution. The potentiodynamic measurements were initiated at $-0.7 \mathrm{~V}$ and scanned continuously toward the anodic direction at $1 \mathrm{mV} \mathrm{s}^{-1}$. The data were analyzed with the PAR 342 Corrosion Measurement Software. A detailed explanation of the procedure and analysis of the results can be found in [25].

\section{Results and Discussion}

Potentiodynamic polarization curves have been measured at 25,40 and $50^{\circ} \mathrm{C}$. Figures 1 and 2 show typical results obtained at $25^{\circ} \mathrm{C}$ for stainless steel (ss) without coating and untreated, ss without coating but heat treated at $800^{\circ} \mathrm{C}$ during $2 \mathrm{~h}$, ss with $\mathrm{ZrO}_{2}$ coating $\left(800^{\circ} \mathrm{C} / 2 \mathrm{~h}\right)$, ss with $\mathrm{SiO}_{2}$ coating $\left(800^{\circ} \mathrm{C} / 2 \mathrm{~h}\right)$, ss with $\mathrm{SiO}_{2}-\mathrm{Al}_{2} \mathrm{O}_{3}$ coating $\left(800^{\circ} \mathrm{C} / 2 \mathrm{~h}\right)$, and ss with $\mathrm{SiO}_{2}-\mathrm{TiO}_{2}$ coating $\left(800^{\circ} \mathrm{C} / 2 \mathrm{~h}\right)$. Similar data have been obtained at the other temperatures.

The protective effect is noticeable for all coatings in both the cathodic and anodic branches of the 
Table 1. Corrosion parameters determined from the potentiodynamic curves measured for stainless steel $316 \mathrm{~L}$ (ss) uncoated and untreated, uncoated but heat treated at $800^{\circ} \mathrm{C} / 2 \mathrm{~h}$, coated with $\mathrm{ZrO}_{2}, \mathrm{SiO}_{2}, \mathrm{SiO}_{2}-\mathrm{AI}_{2} \mathrm{O}_{3}$, and $\mathrm{SiO}_{2}-\mathrm{TiO}_{2}\left(800^{\circ} \mathrm{C} / 2 \mathrm{~h}\right)$ : corrosion potential $E_{\text {corr }}(\mathrm{mV}$ ); polarization resistance $R_{p}\left(\mathrm{k} \Omega \mathrm{cm}^{2}\right)$ and corrosion rate CR (mills per year, MPY).

\begin{tabular}{|c|c|c|c|c|}
\hline Sample & $T\left({ }^{\circ} \mathrm{C}\right)$ & $-E_{\text {corr }}(\mathrm{mV})$ & $R_{p}\left(\mathrm{k} \Omega \mathrm{cm}^{2}\right)$ & CR (MPY) \\
\hline \multirow{3}{*}{$\begin{array}{l}\text { SS 316L } \\
\text { untreated }\end{array}$} & 25 & 286 & 1.80 & 11.5 \\
\hline & 40 & 261 & 0.37 & 35.2 \\
\hline & 50 & 280 & 0.35 & 53.8 \\
\hline \multirow{3}{*}{$\begin{array}{l}\text { SS } 316 \mathrm{~L} \text { heat } \\
\text { treated }\end{array}$} & 25 & 306 & 1.45 & 5.0 \\
\hline & 40 & 304 & 0.57 & 19.8 \\
\hline & 50 & 307 & 0.14 & 41.2 \\
\hline \multirow[t]{3}{*}{$\mathrm{SS}+\mathrm{ZrO}_{2}$} & 25 & 308 & 10.50 & 3.4 \\
\hline & 40 & 328 & 8.50 & 4.2 \\
\hline & 50 & 299 & 0.99 & 12.9 \\
\hline \multirow{3}{*}{$\mathrm{SS}+\mathrm{SiO}_{2}$} & 25 & 289 & 8.56 & 3.1 \\
\hline & 40 & 307 & 1.21 & 6.5 \\
\hline & 50 & 314 & 0.31 & 14.2 \\
\hline \multirow{3}{*}{$\begin{array}{c}\mathrm{SS}+88 \mathrm{SiO}_{2-} \\
12 \mathrm{Al}_{2} \mathrm{O}_{3}\end{array}$} & 25 & 240 & 5.92 & 4.2 \\
\hline & 40 & 297 & 0.93 & 8.4 \\
\hline & 50 & 301 & 0.89 & 13.9 \\
\hline \multirow{3}{*}{$\begin{array}{c}\mathrm{SS}+70 \mathrm{SiO}_{2-}- \\
30 \mathrm{TiO}_{2}\end{array}$} & 25 & 291 & 10.7 & 2.2 \\
\hline & 40 & 297 & 5.70 & 5.7 \\
\hline & 50 & 293 & 3.10 & 6.3 \\
\hline
\end{tabular}

curves. The cathodic part corresponds to the hydrogen evolution reaction $2 \mathrm{H}^{+}+2 \mathrm{e}^{-} \rightarrow \mathrm{H}_{2}$. The slope of the curves for uncoated and untreated stainless steel is ca. $2.3 \times 2 \mathrm{RT} / \mathrm{F}$, where $\mathrm{R}$ is the universal gas constant and $\mathrm{F}$ the Faraday constant a value coherent with a Volmer-Heyrovsky sequence, a current mechanism accepted for this reaction [27]. In the presence of the coatings, the value of the slope is maintained suggesting that the mechanism remains unchanged. However there is a downward shift in the current densities (in the sequence: untreated ss, heat treated ss, $\mathrm{SiO}_{2}-\mathrm{Al}_{2} \mathrm{O}_{3}$, $\mathrm{SiO}_{2}-\mathrm{TiO}_{2}, \mathrm{ZrO}_{2}$ ) indicating that the films act as a geometric blocking; they act as an inert obstacle to exposure of the metal surface to its environment and therefore the reaction rates fall in proportion to the extent of surface coverage. As an example the active area for the reaction is typically reduced by a factor of 10 for the best coating $\left(\mathrm{SiO}_{2} \mathrm{TiO}_{2}\right)$. The chemical attack is probably done via a small remaining open porosity of the film (not observed in SEM measurements) left after the densification heat treatment. The position and the slope of the $\mathrm{SiO}_{2}-\mathrm{TiO}_{2}$ potentiodynamic curves measured in the cathodic range at $25^{\circ} \mathrm{C}$ do not change for heat treatment up to $15 \mathrm{~h}$, all being identical to curve $d$ of Figure 2 indicating that the film surface coverage is not affected by these heat treatments. The measurements performed at $40^{\circ} \mathrm{C}$ and $50^{\circ} \mathrm{C}$ present similar behavior and consequently the blocking properties remain unchanged at these temperatures.

An intermediate behavior is observed for the heat treated substrates without coating (curves b of Figures 1 and 2). It is difficult to interpret it without a detailed knowledge of the processes occurring in the oxide layers growing during the heat treatment on the stainless steel surface as well as in its bulk structure.

The anodic branches of the polarization curves show that the coatings have a strong effect on the current density in the passive region, diminishing the current value of uncoated and untreated stainless steel by roughly one order of magnitude. In the same region, the heat treated uncoated ss samples (curve $b$ of the Figures 1 and 2) show current densities somewhat higher than those of the untreated substrates (curve a) revealing again surface changes during the treatment.

The combined cathodic and anodic effects of the coatings on the corrosion behavior of $316 \mathrm{~L}$ stainless steel are summarized in Table 1, which presents the relevant corrosion parameters derived from computer analysis of the potentiodynamic curves. The values of 


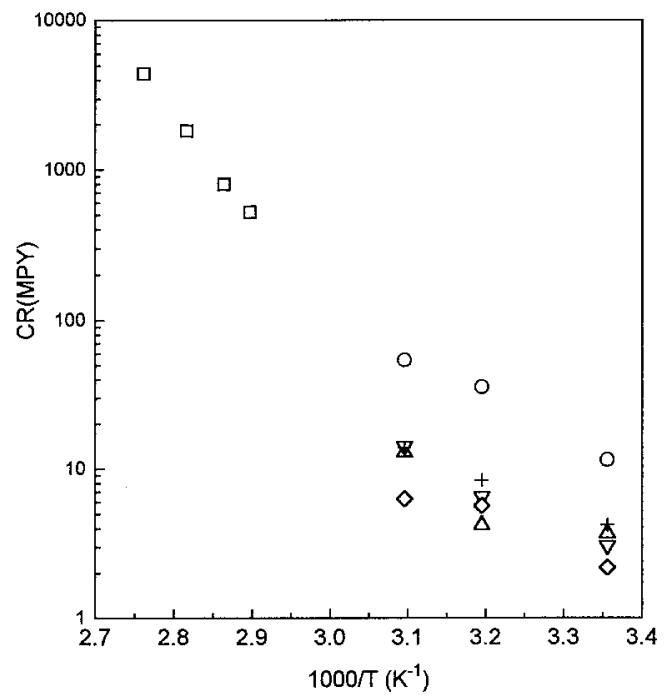

Fig. 3. Temperature dependence of the corrosion rate (MPY) in deareated $15 \%$ aqueous $\mathrm{H}_{2} \mathrm{SO}_{4}$ solution of $316 \mathrm{~L}$ stainless steel: $(\square, \circ)$ uncoated and untreated; the high temperature data $(\square)$ arefrom [19] and have been obtained by weight loss in non deareated solution; $(\nabla)$ coated with $\mathrm{SiO}_{2} ;(\triangle) \mathrm{ZrO}_{2} ;(+) \mathrm{SiO}_{2}-\mathrm{Al}_{2} \mathrm{O}_{3}$ and $(\diamond) \mathrm{SiO}_{2}-\mathrm{TiO}_{2}$.

the corrosion potential $\left(E_{\text {corr }}\right)$ are very little affected by the presence of the films indicating a balance between cathodic and anodic effects. However the polarization resistances $\left(R_{p}\right)$ which reflects the kinetics of the process at the equilibrium potential and the corrosion rate $(\mathrm{CR})$, measured in mill per year, are drastically changed. At all tested temperatures all coatings show a lower corrosion rate than the untreated and uncoated substrate. The lifetime of the coated substrates is increased typically by a factor 3,5 to 5,5 at $25^{\circ} \mathrm{C}$. The effect is even more pronounced at $40^{\circ} \mathrm{C}$ (4 to 8 ) and reaches 8.5 for $\mathrm{SiO}_{2}-\mathrm{TiO}_{2}$ at $50^{\circ} \mathrm{C}$ but decreases to 4 for the other coatings. Even in relation to the heattreated uncoated ss samples, which appear to be more acid resistant than the untreated samples, the effect of the coating is still considerable.

The corrosion rates determined for the different coating compositions heat treated at $800^{\circ} \mathrm{C}$ for $2 \mathrm{~h}$. increase with the temperature of the electrolyte (Figure 3). The low temperature data show the same overall Arrhenius behavior (activation energy $E=27-28$ $\mathrm{kcal}$ mole ${ }^{-1}$ ) for all coatings as well as for the uncoated stainless steel. For the oxide coatings however the preexponential factor is smaller. This confirms that the layers act as a geometric blocking. The data at high temperatures have been determined by weight loss measurements in non deareated $\mathrm{H}_{2} \mathrm{SO}_{4}$ solution
[19]. In order to truly compare these values to those determined electrochemically the measurements should have been extrapolated at zero time which was not possible due to the lack of sensitivity of the method. Non deareated acid solutions are also known to accelerate the corrosion phenomena [26].

The corrosion rates have been also studied as a function of the heat treatment time at $800^{\circ} \mathrm{C}$ (Figure 4). The protection action is basically the same up to around $15 \mathrm{~h}$. This shows that the film surface coverage of the substrate and probably the structure of the pores are not changed during the heat treatment. There is however a drastic change observed at $t=20 \mathrm{~h}$, where the corrosion rates reach the same very high value (CR $\sim 39 \mathrm{MPY}$ ) for all systems (higher than that of the as received stainless steel (11.5 MPY at $t=0)$. SEM measurements show that the films are dense with no visible porosity but are completely broken leaving an easy access of the electrolyte to the substrate (Figure 5). The physical reasons of this decohesion is the growth of a layer of $\mathrm{Cr}_{2} \mathrm{O}_{3}$ single crystals (containing also mainly $\mathrm{Mn}$ and $\mathrm{Fe}$ ) at the interface metal-coating causing significant stresses in the film and leading eventually to its fracture under prolonged high temperature treatment. The growth of the single crystals already occurs at $450^{\circ} \mathrm{C}$ as confirmed by Rutherford Back Scattering measurements [28].

\section{Conclusion}

Sol-gel coatings of $\mathrm{ZrO}_{2}, \mathrm{SiO}_{2}, 70 \mathrm{SiO}_{2}-30 \mathrm{TiO}_{2}$ and $88 \mathrm{SiO}_{2}-12 \mathrm{Al}_{2} \mathrm{O}_{3}$ compositions have been prepared from sonocatalyzed sols and deposited by dip coating technique of 316L stainless steel foil. All the coatings protect the metallic substrate against acid (15\% $\mathrm{H}_{2} \mathrm{SO}_{4}$ ) corrosion. The films are shown to act as a geometric blocking layer and increase the lifetime of the substrate by a factor up to 8.5 , the effect being more pronounced at $50^{\circ} \mathrm{C}$ than at room temperature. The electrochemical parameters such as the corrosion potential, polarization resistance and corrosion rate have been determined. These results, together with those already published on the corrosion obtained in $\mathrm{NaCl}$ solutions [25] confirm the outstanding corrosion protection behavior of thin sonocatalyzed sol-gel oxide 


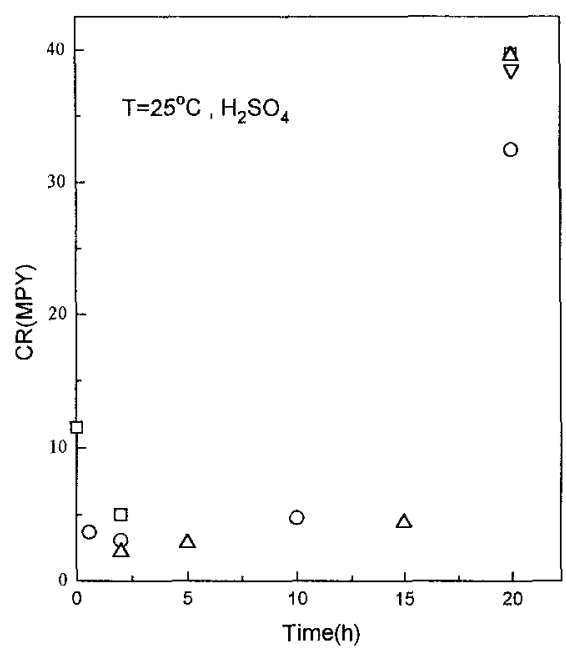

Fig. 4. Corrosion rate (MPY) versus time of heat treatment at $800^{\circ} \mathrm{C}$ measured at $25^{\circ} \mathrm{C}$ in $15 \% \mathrm{H}_{2} \mathrm{SO}_{4}$ for $(\square) \mathrm{ss}$, (o) $\mathrm{SiO}_{2},(\triangle) \mathrm{SiO}_{2}-$ $\mathrm{TiO}_{2}, \nabla\left(\mathrm{SiO}_{2}-\mathrm{Al}_{2} \mathrm{O}_{3}\right)$.

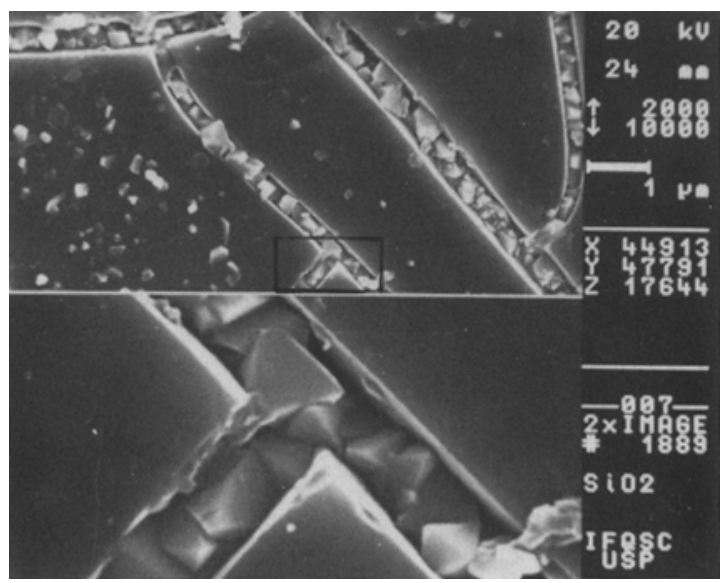

Fig. 5. SEM micrograph of a $\mathrm{SiO}_{2}-\mathrm{TiO}_{2}$ coating heat treated at $800^{\circ} \mathrm{C}$ during $20 \mathrm{~h}$ showing the fracture of the coating due to the growth of $\mathrm{Cr}_{2} \mathrm{O}_{3}$ single crystals at the metal/coating interface. The lower part is a 5 times amplification of the inset shown in the micrograph.

films which can be practically used by the chemical and construction industries.

\section{Acknowledgments}

This research was supported by Fapesp, Finep, CNPq, CAPES/PICD and the Program RHAE-New materials (Brazil).

\section{References}

1. Brinker, C.J. and Scherer, G.W., Sol-gel Science: the Physics and Chemistry of Sol-gel Processing (Academic Press, San Diego, 1990).

2. Sakka, S., in Sol-Gel Science and Technology, edited by Aegerter, M.A., Jr., M.J., Souza, D.F., Zanotto, E.D., (World Scientific, Singapore, 1991) pp. 346-374.

3. Dislich, H., in Sol-Gel Technology for Thin Films, Fibers, Preforms, Electronics, and Specialty Shapes, edited by L.C. Klein (Noyes Publications, Park Ridge, W, 1988) pp. 50-79.

4. Pettit, R.B., Ashley, C.S., Reed, S.T., and Brinker, C.J., in Solgel Technology for Thin Films, Fibers, Preforms, Electronics and Specialty Shapes, edited by L.C. Klein (Noyes Publications, Park Ridge, 1988) pp. 80-109.

5. Schmidt, H., in Chemistry, Spectroscopy and Applications of Sol-Gel Glasses, edited by R. Reisfeld, C.K. Jorgensen (Springer-Verlag, Berlin, 1992) pp. 119-152.

6. Sakka, S. and Yoko, T., in Chemistry, Spectroscopy and Applications of Sol-Gel Glasses, edited by R.R., J.C.K. (SpringerVerlag, Berlin, 1992) pp. 89-118.

7. Jones, D.A., Principles and Prevention of Corrosion (Maxwell-MacMillan, 1992)

8. Schreir, L.L., Corrosion (Newnes-Butterworths, 1976), vol. 2.

9. Schlichting, J., and Neumann, S., J. Non-Cryst. Solids 48 (185), (1982).

10. Martinsen, J., Figat, R.A., and Shafer, M.W., Mat. Res. Soc. Symp. Proc. 32 (361), (1984).

11. Brow, R.K. and Pantano, C.G., Mat. Res. Soc. Symp. Proc. 32 (361), (1982).

12. Ogiwara, S. and Kinugawa, K., Yogyo-Kyokai-Shi (in Japanese) 90 (157), (1982).

13. Matsuda, A., Matsuno, Y., Katagama, S., Tsuno, T., Tohge, N., and Minami, T., J. Ceram. Soc. Jpn., Int. Ed. 100, 1079-1082 (1992).

14. Sanctis, O., Gomez, L., Pelligri, N., Parodi, C., Marajofsky, A., and Duran, A., J. Non-Cryst. Solids 121 (338), (1990).

15. Tohge, N., Matsuda, A., and Minami, T., J. Am. Ceram. Soc. 70 (C13), (1987).

16. Guglielmi, M., Festa, D., Innocenzi, P.C., Colombo, P., and Gobain, M., J. Non-Cryst. Solids 147-148, 474-477 (1992).

17. Di Giampaolo, A.R., Puerta, M., Lira, J., and Ruiz, N., J. NonCryst. Solids 147-148, 467-473 (1992).

18. Atik, M. and Aegerter, M.A., J. Non-Cryst. Solids 147-148, 813-819 (1992).

19. Atik, M. and Zarzycki, J., J. Mat. Sci. Lett. (accepted), (1993).

20. Tomasi, A., Scardi, P., and Marchetti, F., Mat. Res. Soc. Symp. Proc. 271, 477-483 (1992).

21. Atik, M. and Aegerter, M.A., in Better Ceramics Through Chemistry V, edited by Hampden-Smith, M.J., Klemperer, W.G., Brinker, C.J. (MRS, Pittsburgh, 1992), vol. 271, pp. $47 \mathrm{I}-476$.

22. Ganguli, D., and Kundu, D., J. Mat. Sci. Lett. 3 (503), (1984). 
23. Izumi, K., Tanaka, H., Uchida, Y., Tohge, N., and Minami, T., J. Non-Cryst. Solids 147-148, 483-487 (1992).

24. Maggio, R.D., Scardi, P., and Tomasi, A., Mat. Res. Soc. Symp. 180 (481), (1990).

25. Lima Neto, P., Atik, M., Avoca, L.A., and Aegerter, M.A., J. Sol-Gel Science and Tech. (accepted), (1993).
26. Uhlig, H.H. and Revie, R.W., Corrosion and Corrosion Control. J.W. \& Sons, Eds., New York, 1985).

27. Bockriss, J.O,, and Reddy, A.K.N., Modern Electrochemistry (Plenum Press, 1970), vol. 2.

28. Lima Neto, P., Atik, M., Acquadro, J.C., Avaca, L.A., and Aegerter, M.A., (to be published), (1993). 